\title{
Two Pole-Vaulters of Their Times: The Poetry of John Wilmot, Earl of Rochester, and Irving Layton
}

\section{Elena Sánchez Hernández}

This article compares the poetic output of the Anglo-Canadian writer Irving Layton with that of the famous Restoration rake and court poet Fohn Wilmot, Earl of Rochester. Layton himself provided the connection in his wholehearted vindication of the seventeenth century as a time of "intellectual ferment", "criticism and impatience for change". Layton's debt to Nietzsche and Rochester's to his contemporary philosopher Hobbes, respectively, provide the thread through which a striking similarity of values and thematic concerns, of the quality of the amatory experience described; of their criticism of mankind, its institutions and even of themselves, on the one hand, and, on the other, of shared poetic formulas, sources of inspiration (classical, Elizabethan, satiric) and idiom string together in creative work that displays quite striking affinities, the product of similar vital stances.

\section{Keywords}

Dissention; classical/Elizabethan/Restoration/French seventeenth-century literatures; Anglo-Canadian 2oth century literature; lyricists; satirists; trauma; organic poetry; Übermensch/libertine/rake/true wit/hero vs. Massenmensch/ clown/outcast.

\section{Introduction}

... and rather than be less cared not to be at all (Paradise Lost II, 47-48)

Irving Layton dedicates one of his books of poetry to the "pole-vaulters" of the world; to those dissenters whose imagination and courage have contributed to its redemption (The Pole-Vaulter ix) ${ }^{1}$ and, by stating his vocation as the vital necessity to dream and interpret mankind's dreams, he includes himself among them. Another poet who deserves such a title is John Wilmot, Earl of 
Rochester, whose intellectual and emotional honesty made him a great nonconformist of his time.

The connection that inspired this article originated not only from Layton's wholehearted vindication of the seventeenth century as a time characterized by an "intellectual ferment" parallel to the atmosphere of "criticism and impatience for change" (1972: 9) that assisted the birth of his own literary career, his debt to Nietzsche as well as Rochester's particular interpretation of Hobbes's philosophy also provide very interesting points of engagement between two poets whose literary outputs show such striking similarity in their use of poetic formulas, themes and in the terms that give voice to their literary and vital concerns.

Both men witnessed severe socio-political changes which contributed to altering their worlds. On the one hand, the English Civil War and the execution of Charles I brought about a period of confusion but also of intense intellectual reforms which favoured a reaction against the Puritan repression and the Cavalier idealism after the monarchic restoration of Charles II. Returned from exile, young aristocrats like Rochester began to suffer anxiety about the state and to doubt about their own legitimacy, alternatively debating between the assertion and the loss of the privileges traditionally inherited by their class. On the other hand, the traumatic experience of World War II with the mass extermination of Jews by the Nazis, the slave camps of Communist Russia, and such raids as the one on Hiroshima, revealed an "almost complete apathy [towards] human suffering and misfortune" (The Shattered Plinths xiii) ${ }^{2}$, which led Layton to conclude that "the plinths of christianity [sic] and humanism lie shattered and useless, their broken surfaces possible stoops for doves and pigeons" ( $S P \mathrm{xv})$.

As lyricists they wrote love poems celebrating the joy, energy, and passion of the amatory experience and lamented the absence of the loved one. As satirists they lashed out at the stupidity, hypocrisy, ambition, corruption and numbness of mankind and its institutions, sparing no one, not even themselves.

Their thematic concerns - poetry, the human predicament, evil, religious orthodoxy, God, death, love, sex - remained as perennial as the necessity for their own exploration, self-discovery, and renewal through the use of a great variety of poetic forms and patterns whose conventionality both writers sometimes share. What is interesting is their manipulation of such sources as the classical, the Elizabethan, and those of seventeenth-century England and France. If Al Purdy defined Irving Layton as "a traditionalist, with a good ear for the modern idiom" (211), John Wilmot's editorial independence as 
an aristocratic wit permitted him to strain the rhetorical possibilities of the existing literary fashions. They also borrowed freely from what most appealed to them. The result reveals a more emotional than intellectual compromise with their sources of inspiration and a poetry full of tensions between convention and imagination, the ideal and the real, instinct and passion, on the one hand, and intellect and reason, on the other; between life and death or creation and destruction.

Their poetry ranges from the urbane lyricism of their love songs and the anecdotal simplicity of many of their epigrams to the vituperation of their satires whose sexual explicitness and bawdy language, resembling, in Roskolenko's words, "a cannon rather than a sword" (Mayne 27) and mainly devised to shock and awaken their readers, have elicited the same grudging acceptance and wide critical abuse as their other polemical writings and defiant behaviour. The most effective weapon they wielded against their enemies was their outspoken arrogance, presenting themselves as poetic outcasts, either heroes or clowns, and exploiting self-made masks and the explicit opinions others had of them.

\section{The two ends of the pole: Nietzsche and Hobbes}

\subsection{Poetry and the role of the poet}

According to Nietzsche, one of Layton's greatest vital and literary influences, life and art are deeply connected - art being that power that protects life against itself (Safranski 305). For Layton, as for Rochester, writing poetry revealed itself not only an almost organic necessity $(P V$ xi) but as the appropriate means through which they explored and recreated themselves and their worlds constantly, poem after poem, dying and over(be)coming with each new one.

Layton's view of the poet as "someone who has a strong sense of self and feels his life to be meaningful", one who "by insisting on that self and refusing to become the socialized article that bureaucrats, priests, rabbis, and so-called educators approve of, [...] offends the brainwashed millions who are the majority in any country" (1972: 120), has usually been associated with the gifted individual in whom the creative urge is strongest, the Nietzschean Übermensch or Overman.

The Übermensch has no master but himself, according to Francis, "he recreates himself through self-knowledge and self-discipline. He is a passionate 
man who learns to control his passions; a man of reason who trains himself to act rationally as if by instinct; a suffering man who takes joy in life whatever the cost. He exults in the will-to-power which pulses so strongly through him driving him to 'cultivate' himself, to strive continuously toward higher modes of being" (48). But Nietzsche's Overman has other, less idealistic, qualities that associate this model to that of a Cesare Borgia, characterized by having a vigorous and a ludic nature, whose law is action and traditional morals and rules are obstacles in a race towards freedom; one who should learn to dominate his vices and virtues and put them to the service of the achievement of what he considers his superior aim: the art of life itself $(277-78,281-84)$. In this sense the Übermensch is a Dionysian reveller who shares many qualities with the libertine or rake of the Restoration.

Like the French libertins (Théophile de Viau, Jaques Vallé Desbarreaux), the English libertines were disciples of Epicurus and his followers Lucrece and Gassendi. They defended instinct against reason (intellect) and their particular interpretation of Hobbes's materialism, anticlericalism, determinism, and moral relativism had taught them to liberate themselves from the fear of superstition and from an omnipotent but distant and indifferent God. Michel de Montaigne's individualism and obsessive search for happiness were also irresistibly appealing to a number of young courtesans who, like Rochester, aspired to possess the true wit, a sort of intellectual and spiritual aristocracy.

Libertinism then began to be associated with a basically sceptical and defiant attitude that urged the young rakes to go against moral and social rules in their search for freedom and to question, at least in theory, the traditional role of women. The radical quest for pleasure that characterized the libertine revealed a sexually compulsive nature that delighted in the conquest of - even an aggression towards - women and an essentially playful disposition that delighted in the use of disguise to change shape and transform the self if that led to the attainment of his aims. The libertine or rake's destructive impulses which resulted from such radical behaviour were creatively and extensively exploited by John Wilmot, Earl of Rochester, the "mad Earl" (as Thomas Hearne called him), in his poetry.

It is this Dionysian element, described by Layton as a combination of "instinct, emotion, intuition, and madness" (1972: 93), of "love, power, the huzza of battle" 3 that he misses in twentieth-century poetry; the excess and the "demonic visions" (1972: 187) that characterize that seeker of "ecstasy" (1972: 187) that is the Dionysian creator, embodied in the speaker of such poems as "The Solitary" $(P V)$ as one who can "reach out and pluck the stars/ 
one by one/and put them all into [his] notebook", and depicted in the much anthologized "For Mao Tse-Tung: A Meditation on Flies and Kings" $(R C S)$ as dancers, that for Nietzsche and for the Canadian poet symbolize those who have the "freedom to experience, to live life fully and vitally" (1972: 50).

In opposition to the Dionysius-Übermensch the speaker of "For Mao TseTung" refers to the "lowly and universal as the moss", to those who are "like vegetation the wind toss/Sweeping to the open lake and sky", to "the meek in their religious cages", the "joy-haters" and "joy destroyers". These are the Nietzschean Massenmensch ${ }^{4}$, whose world is dominated by technology, whose limited happiness and self-assurance is based on the possession of "swimming pools and a string of lackeys" (Layton 1972: 89), the "intirely satisfyed with theire shares in this world, that theire wishes nor theire thoughts have not a farther prospect of felicity and glory" (Wilmot 1697: 151).

In the Preface to For My Brother Fesus, Layton states that "one of the functions of poetry is to disturb the accumulated complacencies of people, to make them take a fresh look at the reality which habit and custom prevent them from seeing plainly" (xv). He also subscribes his purpose to "de-hypnotize people through outrage, imagination, and truth" (xv). "Nothing finally endures except truth", writes Layton, and for him as well as for Rochester "laughter is mankind's best purgative" (The Covenant $\mathrm{xv}$ ) ${ }^{5}$. So they erected themselves into "scourge[s] to all blockheads" ${ }^{6}$, using their pens as weapons against the vanity, pride, incompetence, ambition, corruption, and stupidity of their contemporaries, and against the institutions of their time using their "elephantine imagination" (Mayne 214) and the expressive potential of exaggeration, obscenity and blasphemy in the same way the Phallic Songs of antiquity used their satirical/magical power "to harm or destroy [its] victims" (Nussbaum 17-18). If Layton considered that "the time for warnings, ... and also for protests, is past" and that "today the poet can only curse... curse long and loud and unceasing, like the incomparable Timon of Athens" (1972: 91, 93), Rochester's (who also chose Timon as one of his alter-egos) conception of satiric writing, as reported by Bishop Burnet, the counsellor of his last days and the author of the Earl's conversion and earliest memoirs, is not that different:

A man could not write with life, unless he were heated by Revenge; For to make a Satyre without Resentments, upon the cold Notions of Phylosophy, was as if a man would in cold blood, cut men's throats who had never offended him ... (Farley-Hills 1972: 54) 
Parallel to the Nietzschean notion that the mark of the noble and strong man is that he has no fear of defending himself when hurt is the Hobbesian recognition of man's lawful right to "rely on his own strength and art, for caution against other men", "if there be no power erected, or not great enough for our security" (Hobbes II.xvii.111). "In a war where no quarter can be expected or given, the poet has no ally but his own integrity and courage and those of a handful of other writers" (Periods of the Moon xiv) ${ }^{7}$.

Layton's "Prologue to The Long Pea-Shooter" and poems like "The Dark Plebeian Mind" (RCS) and "For My Detractors" $(R C S)$ show that same lack of conformity with the established rules, that vision of poetry as an almost physical need, and that aristocratic arrogance Rochester himself revealed in his "Epistolary Essay", whose voice, John Sheffield, Earl of Mulgrave, so much resembles the Earl of Rochester's:

I'm none of those who thinke themselves inspir'd,

Nor write with the vaine hopes to be admir'd;

But from a Rule (I have upon long tryall)

T'avoid with care, all sort of self denyall,

Noe matter tho' the Censring Crittique fret.

Those whom my Muse displeases, are at strife

With equall Spleene, against my Course of life,

... I'd Fart just as I write, for my owne ease,

Nor should you be concern'd unlesse you please:

The speaker of both the "Prologue to the Long Pea-Shooter" and of the "Epistolary Essay" applaud in similar fashion their own literary achievements, claiming that their poetry is better than that of their contemporaries:

So with such wit as I can muster

I surmise I've brought a lustre

To our national verse which before

Was lacking spirit and a bore,

Genteel, dull, and quite anaemic

To please a Bowell or Jasper Shittick:

And though the fat excitable fleas 
Who breed well in our universities

Aver my stuff is unreadable,

Unedifying and unbeautiful

What fool will pay much or close

Attention to these same castratos,

What race will read what they have said

Who have my poems to read instead?9

Such repeated and unwarranted censure is more a stimulus than an obstacle to literary creation. "For My Detractors" $(R C S)$ with a similar tone, though stylistically less close to Rochester's poem, shares the intention to "keepe at home, and write" of the Essay's speaker.

Layton also considers that Canadian critics and reviewers have done little to end the "pervasive and odious prudery" inherited from the Anglo-Saxons and that criticism has missed a chance to demonstrate something more than mere parasitism (1972: 158), becoming, like Northrop Frye's, a "joyless taradiddle" (1972: 174). Poetry has been reduced to "the gimmickry of breath control" (1972: 175) or "word jugglery" ${ }^{\circ}$; to a discipline anyone can adhere to gain academic and social respectability, since critics prefer "poets with a touch of colic/Who'll speak in soft, deflated tones/That menace no one's sleep or bones" ${ }^{11}$.

In opposition to their literary tastes, Layton's ars poetica, like Rochester's' ${ }^{12}$, reveals a far more "realistic, frank, tough-minded, and sensual" (1972: 170) type of poetry. In his introduction to Poems for 27 Cents, Layton writes that he is "on the side of the great vulgarians, beginning with Homer and including Shakespeare and Mayakowsky" and that he "dislike[s] verbosity and misty sentiment, the kind of poetry that is quickly labelled 'beautiful' or 'uplifting' by our comfortable middle classes and by our semi-literate custodians of culture" (1972: 96). "Whatever Else Poetry Is Freedom" (RCS), titled Layton. It has to do with everything that is around and affects us: The "blackened eye" he gave his $\mathrm{Kate}^{13}$, "wrecked marriages/disappointments with friends ..."14, "fresh horse-droppings/on the dusty road to Eftalou" ${ }^{15}$, etc. All constitute, like Rochester's "first, and frankest" (Stone 305) complaint about a feminine lack of hygiene ${ }^{16}$, "The Fertile Muck" ${ }^{25}$ the Apollonian poet, giver of form, brings, through reason and imagination, into a special existence in the act of creation.

In his "Allusion to Horace", based on Horace's Satire I.10, Rochester carries out a mild attack on the literary practices and attitudes of John Dryden, 
expressing a number of the views that the poet laureate shared with the Roman poet. Like him with respect Lucilius, and like Layton with respect to Canada's literary scene, Rochester criticizes the rashness and lack of originality, substance, and art that characterizes his former protégé's verses. The earl, like Layton, also reveals his dislike for the indiscriminate applause of the rabble, unable to distinguish "the dull-eyed philistine" from the "Olympian" ${ }^{17}$, which Dryden's weak satires find.

So Rochester shares with the Canadian poet some ideals that the English noble, following Horace, suggests the target of his satire to follow: concentration and economy of expression before wearisome verbiage, pointed humour rather than excessive virulence, and the desire to please "the truly great"18:

But within due proportions circumscribe

What e're you write; that with a flowing Tyde,

The Stile, may rise, yet in its rise forbear,

With useless Words, t'oppresse the wearyed Eare:

Scorne all Applause the Vile Rout can bestow,

And be content to please those few, who know.

I loath the Rabble, 'Tis enough for me,

If Sidley, Shadwell, Shepherd, Witcherley,

Godolphin, Butler, Buckhurst, Buckinham,

And some few more, whom I omit to name

Approve my Sense, I count their Censure Fame ${ }^{19}$.

In spite of his counsels, Rochester's criticism of the poet laureate's arrogant attitude when dealing with the Jacobean and Elizabethan literary glories, whom the English noble greatly admired, turns into harsh vituperation in those poems spurred by the censure and misunderstanding of other poets and critics against whom Layton also reacted. In both Layton's as well as Rochester's poetry impartial and literary criteria give way to a characteristically subjective and selective stance. So poetic impotence is equated to sexual impotence in such satires as Rochester's "My Lord All-Pride" and "On Poet Ninny". Such parallelism is also found in Layton's "Keewaydin Poetry Festival" $(D F)$ and "For the Wife of Mr. Milton"20, among others. Similarly, "Poetess" 
$(S P)$ and the Assorted Letters, like the riposte to Mr. Gerald Taaffe's criticism, in which the Canadian poet refers to the "white coating on his tongue visible a mile off" (1972: 189), also parallel the above-mentioned satires by the English earl, in which the physical is associated with the intellectual deformities of their enemies.

This is the right and prerogative of artists who, like these two poets, set themselves, either into an arbiter of literary fashions (associated with an inherited superior social status), like Rochester, on the one hand, or, in Layton's case, into a poet-prophet with a calling to follow, on the other. Hence, the belief in their freedom not only to pay sincere homage to those they admired ${ }^{21}$, but to virtually annihilate the victims of their satires ${ }^{22}$.

\subsection{The human predicament}

It is difficult "for the true poet to restrain his pity and contempt for the human condition as it is revealed to him in the present century - difficult for him to write for human beings who accept the enslavement and murder of others without protest or execration" (TD ix-x). According to Layton, "perhaps the poet's tightrope is not stretched between sexuality and death, but between love and loathing for the human race" (TD ix-x). The same ambivalent attitude between his disgust and compassion for man's hopeless predicament is found in Rochester's satires. "Man is the diseased animal, spake Nietzsche, spake Freud" (Layton 1972: 89), and the speaker of Rochester's "Tunbridge Wells" states that "humanity is our worst disease".

The prolific Layton dedicated hundreds of poems to analyzing "age-old thoughts/on the human condition" ${ }^{23}$ and to cursing such disease. The ironic and surrealistic "The Way the World Ends" $(R C S)$ and "The Ventriloquist" $(P V)$ show a nightmarish world populated by grotesque puppets similar to the types that parade in Rochester's "Tunbridge Wells", whose absolute weirdness provokes a series of psychosomatic reactions in the speaker of the satire, making him vomit.

Rochester's anxiety and scepticism about man reaches its highest expression in his famous "Satyr", basically inspired by Boileau and Juvenal. In it, as in some of Layton's poems ${ }^{24}$, their authors specifically concentrate upon the envy, malice, hypocrisy, and those (self) destructive impulses that are part of man's nature. If the necessity to survive is the basic instinct that moves animal behaviour, man's actions, disguised as noble deeds, only reveal a wanton and 
obsessive desire for power over his kind and the world that surrounds him. Like Rochester's "Satyr", Layton's “On Being Bitten by a Dog” $(R C S)$ and "For My Neighbours in Hell" ${ }^{25}$, reveal man as the "dirtiest predator of all" ${ }^{26}$ :

Which is the basest Creature Man, or Beast?

Birds, feed on Birds, Beasts, on each other prey,

But savage Man alone, does Man, betray:

Prest by necessity, they kill for Food,

Man, undoes Man, to do himself no good.

With Teeth, and Claws, by Nature arm'd they hunt,

Natures allowance, to supply their want.

But Man, with smiles, embraces, Friendships, praise,

Unhumanely his Fellows life betrays;

With voluntary pains, works his distress,

Not through necessity, but wantonness.

For hunger, or for Love, they fight, or tear;

Whilst wretched Man, is still in Arms for fear;

For fear he armes, and is of Armes afraid,

By fear, to fear, successively betray'd.

Base fear, the source whence his best passion came,

His boasted Honor, and his dear bought Fame ${ }^{27}$.

\subsection{Reason and intellect}

Speculative reason is also one of the main targets of Rochester's "Satyr". In opposition to animals, proud man engages in a lifelong search for the mysteries of the universe, "aiming to know that World he shou'd enjoy"28. To this kind of reason, that the speaker's adversarius, a divine, defends as that feature that brings man closest to God, the former prefers a "right Reason", which, based on instinct, suppresses the duality between action and thought, bringing him closer to nature. This very pragmatic, vital and intellectual position with its emphasis on (common) sense was the one defended by the English libertines of the Restoration court and reflected in the Hobbesian materialism through which moral judgement was prompted by man's reaction to external stimuli.

Two centuries later, Nietzsche also expressed his rejection of the negative aspects of what he termed Socratism: the spirit of rational inquiry that "interposes theoretical knowledge between experience and reality"; the 
forces that submit men to the tenets of science, technology, social progress, and political programmes, utterly blinding him to "'spiritual' and aesthetic modes of redemption" (Francis 45), and the resulting levelling influence that suppresses whatever is, or is perceived to be, evil and disruptive (Francis 46). Nietzsche's criticism is amplified to include Christianity as an "ally and instrument to the Socratic state" (Francis 52 n.4), since, being basically characterized by man's depersonalization and self-justification, the Christian moral is the decadent moral par excellence (Safranski 333). Hence his criticism, like Layton and Rochester's, of all closed systems and orthodoxies, as imposed and propagated by such institutions as the state, the school, and the church, breeders of the much-criticized Massenmensch, "slaves" ${ }^{29}$, considered great obstacles for the development of what is strong, of what is joyful and passionate in man, of the Dionysian and creative in him.

Both Rochester and Layton amply devoted themselves to expressing and analyzing in their poetry, prose writings, and letters their rejection of current politics and the evils of intellectualism. In his "Satyr" Rochester considers the politicians and the academics (those "modern Cloystered Coxcombs") of his time, servile providers of "false freedomes, ... and formal lyes". In the accomplished philosophical satire "Upon Nothing", he severely criticizes the ambition and corruption of statesmen and the life-long and painful efforts of intellectuals in their pursuit of "blind Phylosophies". According to the speaker of one of Layton's poems "politics, public and impersonal/as a civic lavatory or bus; /it's the trough at which all push and shove/the rich bastards that have too much/and the poor bastards that don't have enough ${ }^{30}$ ". Higher education institutions are "chicken-raisers" ${ }^{11}$, factories (1972: 195) of docile "dentists" trained to pull the teeth out of that tiger that is poetry (1972: 196). This state of bondage appears to be a necessary condition to "be forever/a Johnny-comelately in the world of culture and thought" ${ }^{2}$, to belong to "the fatal league of the cognoscenti" 33 , the authors of the world's "incurable malady" 34 , whose diagnoses consist of an extreme indifference towards the pain and suffering of others, or worse, of learning how to rationalize atrocities and be a "wellbred" executioner35.

For Nietzsche, as for Layton, these "runts are the problem,/runts who long for the stride and stature/of giants; who hate all truth-telling mirrors" 36 , "lesser people getting on the band wagon, ... holding on to the prophet's robes and reducing the thing [great doctrines such as Christianity, Communism, Socialism, Nationalism] to something they can understand" (Sherman 10). Hence Layton's disillusionment with all political credos, such as Marxism. 
Less dangerous and, in a much more limited sense, quite disturbing, was the presence of the so-called fop, coxcomb, or fool in the scene of Restoration drama, whose political, social, intellectual, and sexual aspirations threatened the status quo of the aristocrat. The insistent efforts of Rochester in such poems as "A Ramble in St. James's Parke" and of an important number of his contemporaries to fight this figure with their pen testifies to the aversion that was directed against them.

\subsection{Religious orthodoxy and its representatives}

Rochester's, like Layton's criticism, is much more scathing in those compositions where they show their distrust of all organized religion, seeing it as amongst the chief life-deniers, whose activities are mainly designed to create prejudices against "the finite and the temporal" (Baker 45).

The earl's "Satyr", "Upon Nothing", and his brief translation of Seneca's Troades are good examples of such a scathing criticism of the church representatives of his time. Mean, ambitious, corrupted, and lustful men who, exercising an absolute monopoly over the spiritual, not only did not live up to the values they pretended to represent, but dared themselves to criticize others' behaviour, including the king's. Blasphemy and obscenity are the weapons Rochester uses to transmit the revulsion he felt before the "holy Cheats" 37 and misty abstractions woven by the church to confuse, frighten, and manipulate the weak ${ }^{3}$.

Anger, anxiety, and impotence are the mixed feelings expressed in a good number of Layton's poems ${ }^{39}$ before the hypocrisy and big business that characterize what the Canadian poet calls Xtianity. However, neither are the Jewish institutions exempt from the weaknesses of their delegates, as the amazed speaker of "Synagogue in West Palm Beach" (WPf) nostalgically declares.

The centuries-old libel that Jesus (so wholehearted and affectionately vindicated in For My Brother Fesus) was murdered by the Jews, coupled with the pessimism and hatred of life that characterizes such pseudo-Christianity were, according to Layton, responsible for the killing of millions of Jews by Europeans "with the blessings of popes, bishops, and priests" (FMBJ xvii), as is passionately denounced in "Song of a Frightened Jewish Boy" $(P M)$ and "The Crucifixion" $(C)$.

Rochester was also only too familiar with the extent of such "psychosis" and "ignoble lies" $(C$, xii) in questions that pertained to religion, like the Popish 
Plot, one of the fiercest anti-Catholic periods of the history of England, testifies to, anticipating the accession of the Catholic Duke of York to the throne.

If God has died, as Nietzsche and Layton claim, because modern man has discovered that he has invented $\mathrm{Him}^{4}$, a new religion and a new God will be embodied by him. But this capacity to continue with man's drama belongs only to the Übermensch, the creator ${ }^{41}$, not to the weak Massenmensch whose nihilism makes dogma - "a superstition", "the mental effluvium they call faith or belief" 42 - lead them by their noses.

Having taken the place of "discredited clericals" (SP xii), "the WASPs in poetry" - elsewhere called the "lying" poets" (1972: 81) -, "hand out little white pills to the weary world sufferers" (1972: 81), "anodynes ... advertised as energy-building tonics" (SP, xii), like the poems of Eliot, Auden, Yeats, Frost, and Pasternak in which they "freely [advise] others how to live/when their own lives .../are screwed up"43. These are depicted as "talented beasts"44, "tamed bears/toothless tigers/caged lions .../poets/who dish out the familiar idealistic crap" 45 , looking "so solid and respectable/While stuffing their built-in garburetors with the rubbish of daily living"; so "ridiculous" with their clothes hanging loosely on their indecent selves ${ }^{46}$, or "soft as a boiled potato" 47 .

Yet Layton's relationship with God seems to be more complex than simply denying His existence. He claimed that as his Creator, he loves God. "The Lord", states he in his review of A.M. Klein's Poems,

has been a member of the Jewish family for such a long time that disagreement with Him about His conduct is almost in the nature of a domestic quarrel. To the Jew He is an Elder Relative; in His more expansive mood, the generous uncle, portly and a trifle deaf. To them $\mathrm{He}$ is neither a mystery nor the gaseous, elaborate construction of the metaphysicians. (1972: 26)

However, if in some of his poems God appears quite familiar to their speakers as having a hoarse voice $4^{8}$ and a "celestial cheesecake smile" 49 , in others ${ }^{50}$ $\mathrm{He}$, like the Lucretian ones, as seen in the few lines that Rochester chose to translate from the Roman poet, is depicted by their angry and impotent speakers as an absolutely undecipherable, indifferent, and even a pathetically cowardly God.

God for Layton is also the Dionysian artist who is able to take advantage of the manifestations of his primitive instincts, or the potentially despicable acts of his corrupted nature, to create: "To know God truly, one must also 
have known Satan" (1972: 26). Man can be redeemed through art. Hence the Canadian poet exploits his anger and exorcises through his writings his need for revenge and defence provoked by man's violence to man, and especially by that victimization to which his race has always being subject to, in poems in which he vindicates violence, brutality, as the only means man has to be humane again, if only for "self-interest" ( $S P \mathrm{xv})$, "accommodation", since, according to Layton, "peace" is not "secured by begging for it on one's knees" ${ }^{1}$ (1972: xiv). The strong reflective potential of such poems as "For My Two Sons, Max and David" (SP), "The Coming of the Messiah" $(P M)$, and "After Auschwitz" $(U E)$, certainly provokes a reaction of revulsion as is also clearly seen in Rochester's drunken reveries and the supposedly brutal acts (ascribed to him and to other rakes of Charles II's court) against his enemies and the symbols of their power, such as the glass sundial at Whitehall - emblem of a deceptive king, mortality, and God himself-, which are exploited in such libertine poems as "Regime d'viver" and "To the Post Boy".

When "the old lights are broken,/Politics, religion, Conscience, the perplexity of right and wrong", everything will be reduced to "fug", to "hovering mist" ${ }^{2}$, or, according to Rochester, to nothing 53 . "Queer Hate Poem" (SP), "Leviathan" $(P V)$, and "Holocaust" $(U E)$ reveal the pessimism and impotence that result from man's only certainty, that he is irretrievably lost in a "senseless" 54 universe. However, this pessimism, like in Rochester's "Satyr", is balanced with some hopes for mankind; their scepticism contrasts with their desire to believe in man's possibilities in this world as seen in "Come Closer, Brothers" $(C)$ and in those poems in which Layton uses violence as revulsive.

\subsection{Death}

For Rochester as for Layton the idea that Paradise, if anywhere to be found, should be here on earth appears in their poetry reinforced by the consciousness of their own mortality 55 and by their feeling that if any life should exist after death it consisted of some "recycling of matter" ( $D F$ xii) as seen in Layton's "Street Funeral" $(D F)$ and Rochester's translation of a few lines from Seneca's Troades in which he introduces an original image to state that "dead, wee become the Lumber of the World".

That is why Layton felt at his most Dionysian in cemeteries (1972: 6o-62): to have a good death, one must first have a good life, as the Overman of "Beach Acquaintance" ( $P M)$ states. The thrill that the consciousness of the 
fleetingness of life provoked in him is only increased by the thought of the democracy death brings about and its elimination of the despicable people of this world as seen in such poems as "Sir" (TD) and "Bravo Death, I Love You" (TD). Layton, as the speakers of his poems, felt "safest in cemeteries" where "horizontal humans lie peacefully; /no anger and mischief in them, no hate" ${ }^{6}$. In this sense, "death is akin to art, and artists please/To the measure they have stilled the contraries" 57 . But, as his poetry demonstrates, Layton constantly rebels against death through art. His poems, like Rochester's, do not always show that equilibrium of the Apollonian (form) and the Dionysian (energy). Moreover, each new composition constitutes a permanent rebirth of experience, a constant pole-vaulting over [their] grave ${ }^{8}$.

These ideas coexist alongside the need to believe that there is no absolute end as seen in Layton's "Australian Bush" (PV), in which "all the brown dead leaves/ strewn along the road/Keep telling" the Layton's persona "there's no death, /the black wounds and sores/of dateless trunks/mouth [his] resurrection". Rochester also believed (a necessity imposed by his serious illness) in a future state after death, whose conception, based on the transformations and rebirth of the soul into a different state, as recorded by Bishop Burnet (Farley-Hills 1972: 64), has been defined by Prinz as a "quite Buddhistic" one (223).

\subsection{Love and sex}

Layton also rebels against death through love. In "The Fertile Muck" (RCS) we read: "How to dominate reality? Love is one way;/imagination another" 59. For Rochester, as for the Canadian poet, poetry revealed itself as the only means he had to reconcile (or, at least, try to) the tensions of his complex life. Love as an enriching experience is also a recurring theme in his poetry. In a time when new empirical, materialistic, and pragmatic ideas were gaining ground, Rochester set himself out to experiment with the inherited Petrarchan and, through it, courtly-love tradition combining, juxtaposing, and varying the possibilities these offered as a way of adjusting literature to reality. This correspondence becomes clearer in those poems in which Rochester's greater concern with the philosophical and vital attitudes of libertinism take shape.

In such poems as "Plea for My Lady" (UE), which conveys an almost Petrarchan lyricism in its use of the conventionally disdainful lady who is also the lover/mariner's lodestar; "Love's Diffidence" $(R C S)$ and "Aubade" $(U E)$, which analyze the desperate anger and fragility of one who cannot imagine himself without love, and "Love is an Irrefutable Fire" $(R C S)$, which proclaims 
the ecstasy of the Dionysian reveller, Layton deals with that "sweet torture [that] transforms our grasping unpleasant selves into temporary divinities ... the emotion that makes us endurable to one another ... the alchemist on our blood and gonads converting the shabby materials of our days and weeks into incandescent golden raptures, giving our cloddish lives lustre and grace" (1972: 98) in strikingly similar terms, tone, and sentiment as described by Rochester's Artemiza in a letter she writes to Chloe in the country when she refers to love as

the most gen'rous passion of the mynde

That Cordiall dropp Heav'n in our Cup has throwne,

To make the nauseous draught of life goe downe

On which one onely blesssing God might rayse

In lands of Atheists Subsidyes of prayse

(For none did ere soe dull, and stupid prove,

But felt a God, and blest his pow'r in Love)

Rochester and Layton amply devoted themselves to analyzing the joys and glories of sex as well as its miseries and disorders in much more explicit poems that have generated controversy and have usually been subject to the criticism and censure of the more conservative sectors of the Canadian and European literati.

According to Burnet, Rochester "thought that all pleasure, ... was to be indulged as the gratification of our natural Appetites. It seemed unreasonable to imagine these were put into man only to be restrained, or curbed to such a narrowness" (Farley-Hills 1972: 57) and that "restraining a man from the use of Women, Except in the way of Marriage, and denying the remedy of Divorce, he thought unreasonable impositions on the Freedom of Mankind" (Farley-Hills 1972: 57, 72). An analogous vital attitude characterized Layton, who "was for life, as opposed to restrictions upon life" and who "felt that the body, sex, the world itself were to be enjoyed, praised and celebrated" (Mayne 126).

Layton pays tribute to sex as a rewarding and overpowering experience in countless poems, in which both lovers are "whole ... and there's no breach betwitxt body and soul/under the cursing sun" 60 . Significantly enough, such a perfect communion between sense and human aspirations appears in Rochester's work in the form of two simple exercises of the so-called lucky- 
minute or happy minute poems, "Fair Cloris in a Piggstay lay" and "As Chloris full of harmless thought", in which the bucolic scene and idealistic language that characterize the pastoral romance contrast with a realism that anticipates later treatments of this basic concern in the Earl's poetry, the more interesting the more traumatic the presentation of the sexual encounter.

Literature and sex or the creative and erotic impulses are also associated ${ }^{61}$. Both poets revealed their organic necessities, like the food they ate or Rochester's cherished wine.

Yet their analysis of the amatory experience is not always as positive and vital. Anxiety, pessimism, and fragility before the absence of the lover, either because she has distanced herself, gone, or died, are prevalent in the prolific Layton, especially in The Covenant. On the other hand, Rochester's "The Mistress", the absolutely beautiful "Absent from thee I languish still" and the ambiguous "Att Last you'l force mee to confess" show the painful effects of the speaker's alienating character which imposes his separation, if only temporarily, from the object of his love, seen also in the Canadian poet's "I Would for Your Sake Be Gentle" (RCS).

The anguished impotence and anger product of an alienating mind tortured by fear and the breach between its expectations and reality are extensively dealt with in such poems as the Ovidian "Fiasco" $(F M B \tilde{f})$, which parallels in tone and style the Earl's "The Imperfect Enjoyment". In "The Fall" and "Adam" $(F M B f)$, Rochester and Layton, respectively, vindicate that prelapsarian state of man before The Fall that permitted him to enjoy sex freely since he was one with nature and his mind in perfect harmony with his body.

The potential ecstasies of sex turn into rage and vituperation in those poems that show the castrating effects of intellectualism and religious orthodoxy on women, but there is a basic difference in the position of the speakers of both Layton and Rochester's poetry, marked by the distances in time and the conventionality of the aristocrat's compositions: although these recognize that women are subject to the same passions as men, the concern of the antiplatonic lover in such poems as "The Advice", "To Corinna", and "Phillis, be gentler I advice" mainly rests in the fact that such tyranny is an obstacle to the speaker's obtaining of pleasure. In Layton's poems the speaker's ire concentrates on the submissive character of those who let such tyranny take hold of them, independently of the benefits this can bring him, as seen in "Rose Lemay" (RCS) and "Bedbugs" (PV).

In spite of this, there are numerous examples of their poetry ${ }^{62}$ in which the speakers' rapture only hides a pessimistic hedonism that shows him as 
irretrievably drawn by his indiscriminate sexual drives and by alcohol. The mixture of attraction and revulsion towards sex seen in Layton's "Mahogany Red" $(P M)$ and "September Woman" $(P V)$ as well as in Rochester's "The Platonick Lady", "On Mistres Willis", and "By all Loves soft, yet mighty Pow'rs" also reveal a tired perception of it.

Infidelity is also a familiar theme in both poets' analyses of the relationship between man and woman. Many of Layton's poems show perfectly serene speakers who value the versatility of the female sexual athletes they happen to be with. Feminine sexual promiscuity is accepted, in spite of the libertine attitudes they embrace ${ }^{63}$. Both poets wrote a good number of poems ${ }^{64}$ that clearly show a vituperation that ranges from the sarcastic to a savage rage whose function, like the Phallic Songs of antiquity, is to hurt the object of their satire, whose "cunt" is compared in their poetry to "her mind", since one reveals itself as universal or undiscriminating as the other.

Despite the distances of time, both poets were witness to changes in the perception of the role of women. If after the English Civil War the development of radical ideas and reforms contributed to the creation of an intellectual atmosphere that questioned the basic principles of society and gave women a status that in many cases was similar to that of men, the success of libertinism in the England of Charles II removed from women that spiritual quality assigned to them by Neoplatonism and Puritanism and recognized that they could be susceptible to the same sexual inclinations as men, to which the prevailing Protestant theology contributed in its acceptance that sex could have other purposes than mere procreation. The twentieth century was decisive not only for the recognition of women's rights but also for the consolidation of such rights, especially after the two world wars during which the active role taken by women had proved vital.

Their poetry certainly shows an ambivalence in their attitudes to the feminine, but if Rochester was a man of his time showing conventional, even negative, attitudes towards women's achievements, perceiving these as threats to his status, it is also true that they frequently reveal themselves as the vehicle through which he projected his desires. He also exposed the social hypocrisy that recognized women's enjoyment of sex only when alone.

Rochester and Layton's sincere tributes to different kinds of women (among them prostitutes) coexist with a severe, even aggressive ${ }^{65}$, criticism that has earned them the label of misogynists, which they ironically exploit in a poetry whose speakers behave like clowns, as in the histrionic "Poetic Fame" (RCS), 
the courtly "To the Girls of My Graduating Class" $(D F)$, the mock-heroic "The Disabled Debauchee", and the anecdotal and perfunctory "Regime d'viver".

Layton's poetry shows clearly sexist speakers who still perceive women as objects of desire, their intellect being accessory to the length of their legs, eyelashes, or the size of their bum. His prose writings also display an unjust disrespect towards women's attainments, shielding his weakness with the stale argument of limiting "inherited physiological, biological, [and] hormonal differences" (Sherman 13). However, such criticism tends to concentrate on certain attitudes the two poets found reprehensible in women. For both the comic or satiric seems to be "a kind of defensive posture in which the male tries to reassure himself that the norm is one of male dominance and that feminine triumphs are aberrations" (Farley-Hills 1978: 56-57).

\section{Conclusion}

The vital and literary attitudes of Rochester and Layton located them on the other side of the conventional world in which they lived. Both were Dionysian rebels who affirmed life and the energy and power of it, whose "joyful and trusting fatalism" - the Nietzschean "amor fati" (Van Wilt 36, 40) - made the Canadian poet derive his strength from necessity and the English noble from the lurid assertion of those transgressions he was frequently accused of by his contemporaries and that certainly characterized his intense but short life.

Their poetry also shows that the outcast can certainly be more threatening, as shown in their satires, "using", according to Milton Wilson, "the enemy's weapons, fighting cruelty with cruelty, vulgarity with vulgarity, power with power, so that victory is a kind of defeat" (Mayne 94). Layton's "inverted didacticism", as Fred Cogswell calls this attitude (Mayne 37) parallels Rochester's "inverted idealism", depicted by Everett as that "game of "losing Loadum' the poet had played morally all his life" (Treglown 35, 36).

Rochester's prominent social status permitted him to attack the system from within, the position of the Jew is equally privileged, since, according to Layton, "in his role as outsider he is in a position to understand or absorb and at the same time to reject or criticize" (Mayne 126). For the latter,

the poet, like the Hebrew prophets, will follow his calling even at the risk of incurring misunderstanding, hostility and alienation ... for inside him 
there is a demon will not let him rest, will not let him live a life of normal usefulness. (1972: 110)

Their arrogance and unashamed rhetoric was the result of healthy anger provoked by the stupidity, ambition, corruption, violence, and indifference of men; a defensive posture against the puritanical, prissy, patronizing, and partial attitudes of their critics.

Rochester tended to move away from the fashionable conventions of his time to make his poetry fit a reality that was more often than not traumatic, especially when sick, disappointed with the world, and fully aware of the fact that the libertine doctrines he espoused only proved that the more he sought the idealized freedom and pleasure they defended, the further these were. On the other hand, Layton's Romantic stance and his eclecticism in the use of poetical forms and idioms of the past sometimes results in a poetry whose reminiscences of a Horace or a Juvenal connect it with that composed by the English Earl in a way that suggests that the similarities that inform their poetic works could be due to more than just a matter of chance.

The result is not always beautiful and brilliant. The ephemeral or banal and the inflammatory coexist with more accomplished compositions, whose thematic concerns are renewed constantly in poem after poem with an energy, frankness, and conviction that push one to read on uncritically. They wrote according to their moods and the arbitrariness of perspective and attainment that their poetry shows reveal the nature of experience itself as their strongest source of inspiration.

But outcasts are not only threatening, they can also be threatened creatures, as is pessimistically and ironically described by Layton in such poems as "The Cold Green Element" (RCS) and "Descent from Eden" (WPf), with their Biblical and Swiftian echoes. The braggadocio of Rochester's "To the Post Boy" only hides, in spite of its affirmation of the threatening attitudes it shows, the fragility of a speaker who sees himself as negatively perceived as the poet's contemporaries saw him.

"Two Poets in Toronto" $(R C S)$ and "Letter to an Irish Poet" $(C)$ are just two of the countless examples that reveal Layton's pessimism about poetry and the role of poets, who are "engaged like Sisyphus in a futile task - to make manifest a glory and laughter no one else is the least bit interested in" (1972: xi). Like in Rochester's "Epilogue to Love in the Dark", their readers prefer clowns or puppets, for, according to Frye, "genuine dignity is inseparable from the ridiculous, just as genuine seriousness is from humour" (Mayne 253). 
Like the clown of Layton's poems both writers struggled to keep up on "the stilts of poetry", creating "an ironic balance of tensions" ( $R C S$ vi) between imagination/convention and reality, the creative and the destructive, passion and reason, pity and contempt, rudeness and decorum, the Apollonian and the Dionysian, or to use Blake's symbolism, Heaven and Hell.

\section{Notes}

1. In further references $P V$.

2. In further references $S P$.

3. "The Birth of Tragedy", A Red Carpet for the Sun. It will further be referred to as RCS.

4. Layton dedicates a good number of poems to criticizing these men characterized by their emptiness, "ease/or a default of imagination ("Concourse at Cataraqui", $R C S$ ), "inflamed imbeciles whom pleasure torments", "gelded men" ("Autumn Lines for my Son", RCS) who "wish/Neither to be beloved not written about/And they will endure history/But will neither celebrate nor praise" ("Project", $R C S)$. See also such poems as "Now that I'm Older" (RCS), "Museum at Iraklion" (PV), and "Sublimation" (For My Brother fesus. In further references FMBf). The parallelisms with Rochester's lines in his epilogue to Circe are amazing: "Poets and Women have an Equall Right/To hate the Dull, who Dead to all Delight/Feel pain alone, and have no Joy but spite./'Twas Impotence did first this Vice begin,/Fooles censure Wit, as Old men raile of Sin,/Who Envy Pleasure, which they cannot tast,/And good for nothing, wou'd be wise at last" (The Poems of John Wilmot, Earl of Rochester). Further references to the poems of the Earl will be based on this edition.

5. In further references $C$.

6. This is how the first editor of Rochester's letters defined him. See The Letters of John Wilmot, Earl of Rochester, 261.

7. In further references $P M$.

8. The Darkening Fire. In further references $D F$.

9. "Prologue to "The Long Pea-Shooter"" (DF).

10. "The Day Aviva Came to Paris", The Stoinging Flesh. In further references $S F$.

11. "Prologue to "The Long Pea-Shooter" (DF).

12. In spite of a time when "the observance of convention was as much guarantee of poetic good manners as conventional behaviour was of good breeding", "the Romantic cult of sincerity is already making an appearance in his [Rochester's] poetry" (Farley-Hills 1974: 134).

13. "Whatever Else Poetry is Freedom" (RCS).

14. "The Skull", The Unwavering Eye. In further references $U E$.

15. "Poetry", (TD).

16. "By all Loves soft, yet mighty Pow'rs".

17. "Prologue to "The Long Pea-Shooter" (DF).

18. "For Max Who Showed Me His First Good Poem" (UE).

19. "Allusion to Horace".

20. Waiting for the Messiah. In further references WFM. Equally interesting are "Poet on Cos" $(P V)$ and "Yeats in St. Lucia" (TD). 


\section{ELENA SÁNCHEZ HERNÁNDEZ}

21. "Refin'd Etherige"; Shadwell and Witcherley, whose "bold Stroakes" show "great Mastery with little care"; Waller "by Nature for the Bays desig'nd"; ("Allusion to Horace"); Shakespeare "that unclimbable mountain" .../that forever unapproachable star" ("Shakespeare" UE); the "real Irish giants - Shaw and Joyce and Yeats" ("Rain at La Minerve", $D F)$, that "pole-vaulter", and Mandelshtam and his "forgotten martyrdom" ("Osip Mandelshtam (1891-1940)" UE).

22. Lee, "the hot-brain'd Fustian Foole"; "blundring Settle", Flatman "that Slow Drudge, in swift Pindarique straines" ("Allusion to Horace"); "zany" Reany and "empty" Marriot ("Prologue to "The Long Pea-Shooter", DF); Yeats and Eliot "those twilight rooks"; Frost and Auden "two sexless frauds" ("Poet on Cos", PV); Smith, Scott, and Dudek "a congregation of sick egotists" ("Keewaydin Poetry Festival", $U E$ ).

23. "Proteus and Nymph" (PV).

24. "Orpheus" $(R C S)$, "The Antipodeans" $(U E)$ and "Excelsior" $(F M B f)$.

25. Wild Peculiar foy. In further references WPJ.

26. "The Predator" $(D F)$.

27. "Satyr".

28. "Satyr".

29. "Satyr" and "Lines for My Grandchildren" (PV).

30. "What I Told the Ghost of Harold Laski" (PV).

31. "Macdonald College 1905-1955" (RCS).

32. "O Cureless Rapture" $(C)$.

33. "The Happening" (TD).

34. "O Cureless Rapture" $(C)$.

35. "The Executioner" $(D F)$.

36. "Runts" (FMBJ).

37. "Satyr".

38. His criticism of the church bears some echoes of the work of two important influences on the Earl's poetry, Thomas Hobbes's Leviathan, especially parts III and IV, and Michel de Montaigne's essays, especially part I.

39. "The Papal Election" (TD), "Idiots", $(C)$, and "Toronto Xmas 1976" $(C)$.

40. Rochester's "Upon Nothing" denies the existence of the divinity by associating God with "Nothing".

41. "Storm at Ydra" (UE).

42. "Opium" (TD).

43. "Rumberto" $(S P)$.

44. "Orpheus" (RCS).

45. "The New Sensibility" $(S P)$.

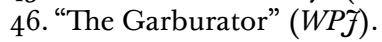

47. "Boris Pasternak" (WPf). See "Saint John the Baptist" (FMBf), where Layton ironically relates such a Messianic attitude as being more proper for such poets as Eliot, Auden, and Yeats than for himself, although he was circumcised.

48. "Women on the Back Streets of Europe" $(P M)$.

49. "Come Out Come Out Wherever You Are" $(C)$.

50. "Latria" $(R C S)$, "For Anne Frank" (PV) "Ad Majorem Dei Gloriam" (UE), "The Smell" $(U E)$, "Warrior Poet" (FMBf), "Digby Dolben" $(C)$, "Bambino", $(C)$ "For Masha Cohen" (TD), and "Late Invitation to the Dance" (TD). 
51. The idea is very much in consonance with Nietzsche's notion of the Overman or Übermensch who defends himself and is able to take revenge upon those who dare hurt him, in opposition to the weak ones or Massenmensch (Safranski 197).

52. "Poem for the Next Century" (RCS).

53. "Upon Nothing".

54. "June Bug" (FMBf). "Nominalist" and "Search", both from WPF, are in the same vein.

55. "The pain and suffering, the loss of pride and dignity, the sacrifice of form and beauty" ( $D F$ xii), the oblivion it brings about, which are obsessively reiterative in Layton's poems. See the three libertine poems by Rochester mentioned above as well as Layton's "On the Death of A. Vishinsky" $(R C S)$, "Take It All In" $(U E)$, "Entry" $(U E)$, "The Mosquito" $(D F)$, "Butterfly on Rock" $(D F)$, "The Red Geranium" (FMBf), "Elysium" $(C)$, "The Garden" (WPf), and "Etruscan Tombs" (WPf). In his memoirs Layton asked "What if the Messiah is life itself, whose sparkling and dithyrambic inflections ask us not to wait but to see and enjoy here and now?" (WFM 90).

56. "Final Reckoning: After Theognis" (WPJ̃).

57. "The Graveyard" $(S P)$.

58. "Pole-Vaulter" (PV).

59. In the autobiographical "Signs and Portents" $(U E)$, in which Layton deals with his early life, parents, education, his views on man, women, politics, and religion, he states that the conclusion he has reached in his life is that "everything except/writing of poems and making love ends up by finally boring me".

6o. "Eden" (TD).

61. See Layton's "Suzanne" $(R C S)$, "Ithaca" $(U E)$, and "Invocation" $(C)$ as well as Rochester's "How perfect Cloris, and how free" and "Second Prologue at Court, [to The Empress of Morocco]".

62. As in Layton's "Bachanal" $(R C S)$ and "Dans le Jardin" $(D F)$ as well as in Rochester's "The Disabled Dabauchee", "Regime d'viver", and "Against Constancy".

63. As in Rochester's "A Ramble in Saint fames's Parke" and in "Upon his leaving his Mistress", and in Layton's "Marie" $(R C S)$, "Fidelity" $(P M)$, and "Out of Pure Lust" (WPf).

64. See Layton's "Archilochus Curses the Woman Who Jilted Him" (PV), "Memo to a Suicide" $(U E)$, "The Worm" $(D F)$, "Island Circe" (FMBf), and "Vita Aeterna" (WPf).

65. See Rochester's "Love a Woman! y'are an Ass", and Layton's "You Come to Me" (TD), and "Freaks" $(C)$, in which women are seen as "the idlest part of Gods Creation" (in Rochester's poem), abnormal beings, "repulsive mammals/without souls" ("Three on a Park Bench", $P M$ ), whose reasons for living seem to lie in men.

\section{Works Cited}

Baker, Howard. "Jewish Themes in the Works of Irving Layton". Essays on Canadian Writing. 7 (1978): 43-54. Print.

Layton, Irving. A Red Carpet for the Sun. Toronto: McClelland and Stewart, 1959. Print.

---. The Sroinging Flesh. Toronto: McClelland and Stewart, 1961. Print. 
---. Periods of the Moon. Toronto: McClelland and Stewart, 1967. Print.

---. The Shattered Plinths. Toronto: McClelland and Stewart, 1968. Print.

---. Engagements. The Prose of Irving Layton. Toronto: McClelland and Stewart, 1972. Print.

---. The Pole-Vaulter. Toronto: McClelland and Stewart, 1974. Print.

---. The Darkening Fire. Selected Poems 1945-1968. Toronto: McClelland and Stewart, 1975. Print.

---. The Unwavering Eye. Selected Poems 1969-1975. Toronto: McClelland and Stewart, 1975. Print.

---. For My Brother fesus. Toronto: McClelland and Stewart, 1976. Print.

---. The Covenant. Toronto: McClelland and Stewart, 1977. Print.

---. The Tightrope Dancer. Toronto: McClelland and Stewart, 1978. Print.

--. Waiting for the Messiah. Toronto: McClelland and Stweart, 1985. Print.

---. Irving Layton. Selected Poems 1945-89: A Wild Peculiar foy. Toronto: McClelland and Stewart, 1989. Print.

Farley-Hills, David ed. Rochester. The Critical Heritage. London: Routledge, 1972. Print.

---. The Benevolence of Laughter. Comic Poetry of the Commonwealth and the Restoration. London: Macmillan, 1974. Print.

---. Rochester's Poetry. London: Bell and Hyman, 1978. Print.

Francis, Wynne. "Layton and Nietzsche". Canadian Literature. 67 (1976): 3952. Print.

Hobbes, Thomas. Leviathan. 1651. Oxford: O.U.P, 1988. Print.

Mayne, Seymour ed. Irving Layton. The Poet and His Critics. Toronto: McGrawHill Ryerson, 1978. Print.

Montaigne, Michel de. Ensayos. Essais 1580-88. Transl. and ed. Dolores Picazo y Almudena Montojo. Madrid: Cátedra, 1985-87. Print.

Nussbaum, Felicity. The Brink of All We Hate. English Satires on Women 1660-1750. Kentucky: U. P. of Kentucky, 1984. Print.

Purdy, Al. Starting from Ameliasburgh. Ed. Sam Solecki. British Columbia: Harbour Publishing, 1995. Print.

Prinz, Johannes. Fohn Wilmot, Earl of Rochester. His Life and Writings. Leipzig: Mayer and Müller, 1927. Print.

Safranski, Rüdiger. Nietzsche. Biografía de su pensamiento. Trans. Raúl Gabás. Barcelona: Círculo de Lectores, 2001. Print.

Sherman, Kenneth. "An Interview with Irving Layton". Essays on Canadian Writing. 10 (1978): 7-18. Print. 
Stone, Lawrence. The Family, Sex and Marriage in England 1500-1800. Harmondsworth: Penguin, 1988. Print.

Treglown, Jeremy (Ed.). Spirit of Wit. Reconsiderations of Rochester. Oxford: Blackwell, 1982. Print.

Van Wilt, Kurt. "Layton, Nietzsche and Overcoming." Essays on Canadian Writing. 10 (1978): 19-42. Print.

Wilmot, John. The Letters of John Wilmot, Earl of Rochester. 1697. Ed. Jeremy Treglown. Oxford: Blackwell, 1980. Print.

---. The Poems of John Wilmot, Earl of Rochester. Ed. Keith Walker. Oxford Blackwell, 1988. Print.

ELENA SÁNCHEZ HERNÁNDEZ is Lecturer in English Literature at the University of La Laguna. She has taught Anglo-Canadian, Medieval, Renaissance and Restoration Literatures as well as ESP (ICT, Electronics Engineering, Building Engineering, Economic Studies and Tourism). She is the author of a number of articles on $20^{\text {th }}$-century British poetry, $17^{\text {th }}$-century English poetry, and $19^{\text {th }}$-century Canadian narrative and contemporary drama. She is the author of the critical essay Conflicto y unidad en la poesía de fohn Wilmot, conde de Rochester (Ediciones Idea. Santa Cruz de Tenerife, 20o9) and editor and translator of the Canadian poet of Polish origin Rachel Korn (Generaciones. Editorial Siníndice. Logroño. Spain, 2013). She is Secretary of the Centre for Canadian Studies at the University of La Laguna and of Canadaria: Canarian fournal of Canadian Studies. elesan@ull.edu 